\title{
Orta Okul Öğrencileri İçin Fiziksel Aktivite Tutum Ölçeğinin Geliştirilmesi
}

\section{Development of Physical Activity Attitude Scale For Secondary School Students}

\author{
${ }^{1}$ Günay YILDIZER \\ ${ }^{2}$ Emre BILGIN \\ ${ }^{3}$ Ezel Nur KORUR \\ ${ }^{2}$ Yılmaz YÜKSEL \\ ${ }^{2}$ Giyasettin DEMIRHAN
}

${ }^{1}$ Eskişehir Teknik Üniversitesi, Spor Bilimleri Fakültesi, Beden Eğitimi ve Spor Eğitimi Bölümü

${ }^{2}$ Hacettepe Üniversitesi, Spor

Bilimleri Fakültesi, Beden Eğitimi ve Spor Öğretmenliği Bölümü

${ }^{3}$ Ordu Üniversitesi, Beden Eğitimi ve Spor Yüksel Okulu, Beden Eğitimi ve Spor Öğretmenliği Bölümü

\section{Yazışma Adresi}

Corresponding Address:

Arş.Gör.Dr. Günay Yıldızer ORCID: 0000-0002-4292-2156

Eskişehir Teknik Üniversitesi, İki Eylül Kampüsü, Spor Bilimleri Fakültesi, Tepebaşı/Eskişehir

E-posta: gunayyildizer@gmail.com
Geliş Tarihi (Received): 01.12.2018 Kabul Tarihi (Accepted): 12.06.2019

\section{öz}

Çocukların fiziksel aktivite düzeyini yükseltmek ve fiziksel aktiviteye ilişkin olumlu tutum geliştirmelerini sağlamak için fiziksel aktiviteye yönelik bakış açıları hakkında bilgiye ihtiyaç vardır. Çocuğun fiziksel aktivite davranışını artırmak için öncelikle fiziksel aktiviteye ilişkin tutumu belirlemek ve sonuçlara göre uygulama stratejileri belirlemek gereklidir. Bu çalışmanın amacı, ortaokul öğrencilerinin fiziksel aktiviteye yönelik tutumlarını ölçmek için Fiziksel Aktiviteye Yönelik Tutum Ölçeği (FAYTÖ) olarak isimlendirilen güncel ve güvenilir bir ölçme aracı geliştirmektir. 2016-2017 eğitim öğretim yılında yürütülen bu araştırma için Hacettepe Üniversitesinden Etik Komisyon onayı ve Milli Eğitim Bakanlığından yasal izin alınmıştır. Çalışmada betimsel tarama modeli kullanılmıştır. Çalışmanın örneklemini ilköğretim 6.7. ve 8. sınıfta öğrenim gören 636 öğrenci oluşturmaktadır. Açımlayıcı $(n=206)$ ve doğrulayıcı faktör analizlerinin $(n=430)$ yürütülmesinde iki farklı örneklem üzerinde çalışma yürütülmüştür. Açımlayıcı faktör analizi sonuçları ölçekteki 25 maddenin 5 faktörde toplandığını göstermektedir: Sevgi ( 5 madde), İsteklilik (7 madde), Fayda (4 madde), Sosyalleşme ( 5 madde) ve Öz Güven (4 madde). Bu faktörlerin yükleri 0.409 ve 0.768 , iç tutarlılık katsayıları ise 0.70 ve 0.85 arasında değişmektedir. Faktörlerin toplam varyansa yaptıkları katkı \%61.16'dır. Ortaya çıkan modelin uyum indeksleri incelendiğinde $\chi 2 / \mathrm{df}=1.96, \mathrm{RMSEA}=0.048, \mathrm{NNFI}=0.927, \mathrm{CFI}=0,937, \mathrm{IFI}=0.937, \mathrm{GFI}$ $=0.909$ 'dur. Elde edilen bu bulgular FAYTÖ'nün 7. ve 8. sınıf ortaokul öğrencilerinin fiziksel aktiviteye yönelik tutumlarının değerlendirilmesinde geçerli ve güvenilir bir ölçme aracı olduğunu göstermektedir.

Anahtar Kelimeler: Fiziksel aktivite, Tutum, Ortaokul öğrencileri

\section{ABSTRACT}

There is a need for perception of children towards physical activity to raise their awareness of physical activity level and to develop positive attitudes towards physical activity. In order to increase the child's physical activity behaviour, it is necessary to first determine the attitude towards physical activity and determine the implementation strategies according to the results. The purpose of this study was to develop an up-to-date and reliable measurement tool called the Attitude Scale for Physical Activity (ASPA) to measure the attitudes of secondary school students towards physical activity. In this study, descriptive study design was used. The sample of the study consisted of 636 6th, 7th and 8th-grade students. Exploratory factor analysis $(n=206)$ and confirmatory factor analysis $(n=430)$ were conducted on different groups. Exploratory factor analysis results revealed 5 factors: Affinity (5 items), Willingness ( 7 items), Benefit (4 items), Socialization ( 5 items) and Self-Trust (4 items). Internal consistency coefficients of these factors were $0.83,0.85,0.75,0.82$, 0.70 , respectively. The contribution of these factors to the total variance was $61.16 \%$ and the factor loadings range was from 0.409 to 0.768 . Confirmatory factor analysis results were $\chi 2 / \mathrm{df}=1.96, \mathrm{RMSEA}=0.048, \mathrm{NNFI}=0.927, \mathrm{CFI}=0.937, \mathrm{IFI}=0.937, \mathrm{GFI}$ $=0.909$. These findings showed that ASPA is a valid and reliable measurement tool for 6th, 7th and 8th grade secondary school students in order to measure attitude towards physical activity.

Key Words: Physical activity, Attitude, Secondary school students 


\section{GíRiş}

Düzenli fiziksel aktiviteye katılmanın çocuk gelişimi ve fiziksel olgunlaşma üzerindeki olumlu faydaları bilinmesine rağmen bireyler önerilen miktarda fiziksel aktiviteye katılmamaktadırlar (Strong ve diğ., 2005; Hills ve diğ., 2007). Bu durum bulaşıcı olmayan ama ölüm riskini artıran birçok hastalığa sebep olduğundan dolayı (WHO, 2010), birçok araştırmaya konu olmuş ve araştırmacılar fiziksel aktivite davranışının bilişsel-davranışsal düzenlemeler ile fiziksel aktivite davranışının arttırılabileceği sonucuna ulaşmışlardır (Marcus ve diğ., 2000; Lewis ve diğ., 2002).

Fiziksel aktivite çalışmalarının büyük çoğunluğu çocuk ve adölesan çağında oluşturulan sağlıkla ilişkili davranışların yetişkinlikte daha tutarlı biçimde devam etmesinden dolayı, bu yaş gruplarındaki bireylere odaklanmaktadır (Halfon ve Hochstein, 2002). Taylor ve diğ. (1999) ile Twisk ve diğ. (2000) fiziksel aktivite davranışlarının erken adölesan dönemde oluşturulmasının, yaşam boyu devam etmesinde önemli olduğunu belirtmişlerdir. Bir başka araştırmada ise, çocuklarda beden eğitimi ve spor dersine ilişkin tutumun pozitif olması çocuğun ileriki yaşlarında fiziksel aktivite veya egzersiz için pozitif tutum geliştirmesine ve düzenli fiziksel aktiviteye katılmasına sebep olabileceği vurgulanmıştır (Linda Rikard ve Banville, 2006). Bu duruma karşın, adölesan dönemde fiziksel aktiviteye katılımın düştüğü farklı kültürde yürütülen çalışmalarca raporlanmıştır (Kemper ve diğ., 1999; Ruiz ve diğ., 2011; Van Mechelen ve diğ, 2000). Türkiye'de de fiziksel aktivite katılımı geniş ölçekli raporlayan çalışmalar adölesan çağdaki bireylerin \%80'nin fiziksel aktivitelere yeterli düzeyde katılmadığını göstermektedir (T.C. Sağlık Bakanlı̆̆ı, 2010; WHO, 2014; Yıldızer ve diğ., 2018).

Çocukların fiziksel aktivite davranışlarını değiştirmenin en etkili yolunun okul içi uygulamalar olduğu vurgulanmaktadır. Bu konu üzerinde yapılan bir araştırmada okul beden eğitimi dersleri, okul yemek servisi, aile katılımları, okul politikası ve öğretim programı fiziksel aktivite davranışı değiştirebilmek için düzenlenmiş ve araştırma sonucunda \%39 civarında fiziksel aktivite davranışında artış görülmüsşür (Luepker ve diğ., 1996). Türkiye’de yürütülen bir çalışmada ise (Cengiz ve İnce, 2014), okul ortamının ve çevresinin sosyo-ekolojik yaklaşımla sağlıkla ilişkili fiziksel uygunluk konusunda desteklendiğinde, fiziksel aktivite ve fiziksel aktivite bilgisi gibi çıktıların olumlu şekilde etkilendiği raporlanmıştır. Bir başka araştırmada ise çocukların fiziksel aktivitelere katılmasında çocuğun ve ailesinin yapılan fiziksel aktivite türünü, fiziksel çevreyi doğrudan gözlemi ve okul politikalarının oldukça etkili yapılar olduğu saptanmıştır (Pate ve diğ., 2015).

$\mathrm{Bu}$ bağlamda, fiziksel aktivite müdahalelerini içeren çalışmaların hedef aldığı temel konulardan birisi yaşam boyu sağlık bilincinin oluşturulmasında, fiziksel aktiviteye yönelik duyuşsal açıdan oldukça önemli olan tutumun geliştirilmesidir. Tutum bir olaya, nesneye, kişiye, kuruma veya benzer bir kavrama olumlu veya olumsuz eğilimler olarak tanımlanır (Deryakulu, 2004). Bu eğilimler bilişsel, duygusal ve fiziksel olmak üzere üç kategoriye ayrılır. Bilişsel eğilimler tutum sergilenecek nesne ile ilgili düşünce ve algılardan, duygusal eğilimler değerlendirme ve hislerden, fiziksel eğilimler ise nesneye karşı davranışlardan oluşur (Ajzen, 2005). Yapılan araştırmalar bir kavrama ilişkin olumlu tutumun bireyin o nesneye ilişkin olumlu düşünmesine ve nesne ile etkileşim halinde iken iyi hissetmesine sebep olabilmekte ve o kavramı ilgili pozitif davranışları göstermesini kolaylaştırabilmektedir (Linda Rikard ve Banville, 2006; Milosis ve diğ., 2015; Ajzen, 2001). Bu his ve davranışın kökenini inceleyen Nedenli Eylem Teorisine (Theory of Reasoned Action) göre tutumlar inançlardan ortaya çıkar, eğilim ve davranış olarak gözlenir (Linda Rikard ve Banville, 2006).

Tutumlar doğrudan gözlemlenemeyecek soyut kavramlardır ancak tutumların gözlemlenebilir somut halleri insanın davranışlarına yansır. Sevgi nefret gibi kavramlar ve bir nesneye ilişkin tutum bireyin davranış ve söylemlerinden dolaylı olarak belirlenebilir (Morgan, 2009). Bu açıdan erken adölesan dönemdeki bireylerin fiziksel aktiviteye yönelik tutumlarının belirlenmesi ve hangi açılardan tutumlarının farklılaştıklarının tespit edilmesi, Türkiye'de görülen olumsuz 
fiziksel aktivite katılım eğiliminin (Aksoydan ve Çakır, 2011), değişime uğramasında faydalı bilgiler ortaya koyabilir. Erken adölesan dönemde olan ortaokul öğrencilerinin fiziksel aktiviteye yönelik tutumlarının değerlendirilmesine olanak tanıyan bir ölçme aracının varlığı bu açıdan önemlidir. Buradan hareketle araştırmanın amacı Türkiye'de 12-15 yaş arasındaki erken adölesan çağdaki bireylerin fiziksel aktiviteye yönelik tutumlarını değerlendirmeye olanak sağlayan ölçme aracının geliştirmektir.

\section{YÖNTEM}

Ortaokul öğrencilerinin fiziksel aktiviteye yönelik tutumlarını inceleyen bir ölçme aracı geliştirilmesini hedefleyen bu çalışma betimsel tarama modeli kullanılarak yürütülmüştür (Fraenkel ve diğ., 2012). 2016-2017 eğitim öğretim yılında yürütülen bu araştırma için Hacettepe Üniversitesinden Etik Komisyon onayı (76000869/431-1241) ve Millî Eğitim Bakanlığından yasal izin alınmıştır. Tüm katılımcılar ve katılımcıların velilerinden onam formları toplanmıştır.

Denekler / Araştırma Grubu / Örneklem: Açımlayıcı ve doğrulayıcı faktör analizlerinin yürütülmesinde iki farklı örneklem üzerinde çalışma yürütülmüştür. Araştırma 12-15 yaş arasında olan, 6. 7. ve 8. sınıf öğrencileri ile sınırlıdır. Açımlayıcı faktör analizi için 206 öğrenciden veri toplanmıştır. Çalışmanın bu basamağına katılan öğrencilerin 85’i kız (\%41.3) ve 121'i (\%58.7) erkektir. Açımlayıcı faktör analizine dâhil edilen öğrencilerin 75'i altıncı, 65'i yedinci ve 66’sı sekizinci sınıftadır. Doğrulayıcı faktör analizi uygulaması için ise Açımlayıcı Faktör Analizine dâhil olmamış 430 öğrenciden veri toplanmıştır. Bu aşamada çalışmaya katılan öğrencilerin 231'i (\%53.6) kız ve 199’u (\%46.2) erkektir. Doğrulayıcı faktör analizi uygulamasına dâhil edilen öğrencilerin ise 141'i altıncı sınıf, 135'i yedinci sınıf ve 154'ü sekizinci sınıftadır.

\section{Veri Toplama Araçları:}

Kişisel Bilgi Formu: Bu çalışmada araştırmacılar tarafından tasarlanan ve ortaokul öğrencilerinin cinsiyet, sınıf ve yaş değişkenlerini içeren kişisel bilgi formu kullanılmıştır.

Fiziksel Aktiviteye Yönelik Tutum Ölçeği: Ortaokul öğrencilerinin fiziksel aktiviteye katılımlarını belirlemek için kullanılan Fiziksel Aktiviteye Yönelik Tutum Ölçeğin geliştirilmesi sürecinde Creswell (2017)'in önerdiği işlem basamağı takip edilmiştir. Bu basamaklama şu şekildedir;

1. Alan yazın derleme, tavsiye için uzman görüşü almak,

2. Olası maddeleri belirlemek,

3. Açımlayıcı faktör analizi ile maddeleri küçük bir örneklem üzerinde test etmek,

4. Ölçek maddelerinin güvenirlik analizini yürütmek,

5. Ölçeği daha büyük bir örnekleme uygulamak,

6. Doğrulayıcı faktör analizi uygulamak.

Ölçek aday maddelerinin oluşturulmasında beden eğitimi öğretmenleri ile fiziksel aktivite ve beden eğitimi ve spor alanında akademik çalışmalarını yürüten öğretim elemanlarından destek alınmıştır. Oluşturulan 56 aday maddenin kapsam geçerliğinin incelenmesi için ise tekrar fiziksel aktivite ile beden eğitimi ve spor alanında uzman olan akademisyenlerden ve beden eğitimi öğretmenlerinden destek alınarak maddelere son hali verilmiştir. Bu aşamada oluşturulan madde havuzunun öğrenciler tarafından anlaşılırlığının tespiti için ise 60 öğrenciden oluşan küçük bir gruba uygulama yapılmıştır. Öğrenciler tüm maddelerin açık ifadeler taşıdığını belirtmiştir. 
Alan yazın derleme ve uzman görüşleri doğrultusunda fiziksel aktiviteye ilişkin tutumu yansıtan 56 aday madde ile ölçek havuzu oluşturulmuştur. Oluşturulan madde havuzu beş farklı alan uzmanı tarafindan incelenmiş ve önerilen düzenlemeler yapılmıştır. Olası madde havuzunda yer alan maddeler pozitif ve negatif anlam içermektedir. 5'li Likert tipinde dizayn edilen ölçme aracında cevaplama skalası " $1=$ Kesinlikle Katılmıyorum", "2=Katılmıyorum", "3=Kararsızım”, “4=Katılıyorum”, “5=Kesinlikle Katılıyorum” şeklindedir ve maddelere verilen cevapların toplam puanına göre bir alt boyuttan alınan yüksek puan yüksek tutumu ifade ederken, düşük puan ise düşük tutumu göstermektedir.

Verilerin Toplanması/İşlem Yolu: Verilerin toplanabilmesi için Ankara İl Milli Eğitim Müdürlüğünden gerekli izinler alınmıştır. Daha sonra veri toplamak için aynı sosyoekonomik düzey ve fiziksel imkânlara sahip dört ortaokul uygun örnekleme tekniği kullanarak belirlenmiştir. Sonraki aşamada ise araştırmaya katılacak öğrencilere ve velilerine araştırma ile ilgili detaylı bilgilerin olduğu; gönüllü katılım formu ve araştırma öncesi bilgi formu verilmiştir. Araştırmaya gönüllü olarak katılmayı kabul eden katılımcılar beden eğitimi dersinde beden eğitimi öğretmeni ve araştırmacılar nezaretinde fiziksel aktiviteye ilişkin tutum ölçeğini doldurmuştur. Ölçeğin doldurulması yaklaşık 10 dakika sürmüştür.

Verilerin Analizi: Yapı geçerliğinin tespiti için önce Açımlayıcı Faktör Analizi (AFA) daha sonra Doğrulayıcı Faktör Analizi (DFA) uygulanmıştır. Açımlayıcı faktör analizi ile belirli bir sayıdaki değişkenden orijinal değişkenliği yüksek oranda açıklayan daha az sayıda faktör belirlenirken; doğrulayıcı faktör analizinde model ve veri arasındaki uyum incelenir (Özdamar, 2013). Genel uyumluluğun tespiti için Ki-kare ( $\left.\mathrm{x}^{2}\right)$ değeri ve buna bağlı olarak Ki-kare değerinin serbestlik derecesi'ne oranı $\left(\mathrm{x}^{2} / \mathrm{sd}\right)$ kullanılmıştır. Normlaştırılmış Uyum İndeksi (NNFI), Yaklaşık Hataların Ortalama Karekökü (RMSEA), Arttırmalı Uyum İndeksi (IFI), Karşılaştırmalı Uyum İndeksi (CFI) ve standartlaştırılmış hata kareleri ortalamasının karekökü (SRMR) karşılaştırmalı uyum indeksleri olarak kullanılmıştır. Ayrıca, mutlak uyum indeksleri arasında, İyilik Uyum İndeksi (GFI) hesaplanarak raporlanmıştır. Açımlayıcı ve doğrulayıcı faktör analizlerinden sonra ölçeğin tamamının ve alt boyutlarının güvenirliğini hesaplamak için ise Cronbach’s Alpha iç tutarlılık katsayısı değerlendirilmiştir. Açımlayıcı faktör analizi SPSS 22 doğrulayıcı faktör analizi ise AMOS programları kullanılarak yürütülmüştür.

\section{BULGULAR}

Açımlayıcı Faktör Analizine Yönelik Bulgular: Fiziksel Aktiviteye Yönelik Tutum Ölçeği’”nden alınan verilerin açımlayıcı faktör analizine uygunluğunu belirlemek için Kaiser-Meyer-Olkin (KMO) katsayısı ve Barlett küresellik test değerleri incelenmiştir. KMO değeri 0.897 bulunurken, Barlett küresellik testi anlamlı $(\mathrm{p}<0.05)$ bulunmuştur. Büyüköztürk (2007) KMO değerinin 0.60'dan fazla olması ve Barlett test değerinin anlamlı bulunmasının veri setinin açımlayıcı faktör analizi için uygun olduğunu belirtmektedir. Veri setinde faktör yapıları değerlendirilirken öz değeri birin üzerinde olan faktörler anlamlı kabul edilmiştir. Korelasyon matrisinde maddelerin en az 0.300 korelasyon değerine sahip olması gözetilmiş ve bu duruma uymayan 6 madde analiz dışında bırakılmıştır.

Geriye kalan 50 madde alt boyutlar arasında maddelerin nitelikli dağılımları ve binişik maddelerin olmaması durumları dikkate alınarak tekrar açımlayıcı faktör analizine dâhil edilmiştir. Bu süreç boyunca maddelerin alt boyutlara kuramsal olarak anlamlı dağıldığı, 5 alt boyutlu ve 25 maddelik bir yapı elde edilmiştir. Açıklanan toplam varyans ise \%61.16 olarak belirlenmiştir. Madde faktör yükleri 0.409 ve 0.768 arasında değişmektedir (Tablo 1). Bu değerin 0.40’ dan büyük olması yeterlidir (Field, 2009). Her bir gözlenen değişkenin t-değerinin $\mathrm{p}<0.05$ anlamlılık düzeyinde 1.960 'dan 
büyük olduğu için modelde tutulmuştur (Kline, 2011). Elde edilen alt boyutlar Sevgi (5 madde), İsteklilik (7 madde), Fayda (5 madde), Sosyalleşme (4 madde) ve Öz Güven (4 madde) olarak isimlendirilmiştir.

Tablo 1. Fiziksel aktiviteye yönelik tutum ölçeğine ilişkin açımlayıcı faktör analizi sonuçları

\begin{tabular}{|c|c|c|c|c|}
\hline Faktör & $\begin{array}{c}\text { Faktör } \\
\text { Yükü }\end{array}$ & t-değeri & $\begin{array}{l}\text { Cronbach Alpha } \\
\text { Değeri }\end{array}$ & $\begin{array}{r}\text { Açıklanan } \\
\text { Varyans }\end{array}$ \\
\hline \multicolumn{5}{|l|}{ İsteklilik } \\
\hline $\begin{array}{l}\text { Fiziksel aktivite esnasında öğretmenimi/ antrenörümü } \\
\text { dinlemem.* }\end{array}$ & 0.76 & 6.59 & \multirow{7}{*}{0.85} & \multirow{7}{*}{$\% 34.85$} \\
\hline Fiziksel aktivite ile ilgili hiçbir şeye ilgi duymam.* & 0.72 & 15.21 & & \\
\hline Fiziksel aktiviteye ailem istediği için katılırım.* & 0.66 & 14.22 & & \\
\hline Fiziksel aktivitelere katılmaktan nefret ederim.* & 0.66 & 17.69 & & \\
\hline $\begin{array}{l}\text { Fiziksel aktivite yaparken boşa zaman harcadığımı } \\
\text { düşünürüm.* }\end{array}$ & 0.62 & 17.30 & & \\
\hline Fiziksel aktivite yapmak sıkıcıdır.* & 0.59 & 17.21 & & \\
\hline Fiziksel aktivite hakkında bir şey bilmesem de olur.* & 0.59 & 13.04 & & \\
\hline \multicolumn{5}{|l|}{ Sevgi } \\
\hline $\begin{array}{l}\text { Okulda daha fazla fiziksel aktivite imkânı olmasını } \\
\text { isterim. }\end{array}$ & 0.76 & 17.52 & \multirow{5}{*}{0.83} & \multirow{5}{*}{$\% 10.38$} \\
\hline $\begin{array}{l}\text { Okulda fiziksel aktivitelere katılmak için zamanın bir an } \\
\text { önce gelmesini beklerim. }\end{array}$ & 0.72 & 17.02 & & \\
\hline $\begin{array}{l}\text { Fiziksel aktivitelere katılmak için daha fazla çevresel } \\
\text { imkâna (Oyun sahası, spor salonu vb.) sahip olmak } \\
\text { isterim. }\end{array}$ & 0.65 & 16.59 & & \\
\hline Fiziksel aktiviteye katılmak beni mutlu eder & 0.64 & 17.24 & & \\
\hline Zamanımın çoğunda fiziksel aktivite yapmak isterim. & 0.62 & 12.71 & & \\
\hline \multicolumn{5}{|l|}{ Fayda } \\
\hline $\begin{array}{l}\text { Düzenli olarak (haftada en az } 3 \text { gün) fiziksel aktivite } \\
\text { yaparım. }\end{array}$ & 0.75 & 11.29 & \multirow{5}{*}{0.82} & \multirow{5}{*}{$\% 5.62$} \\
\hline $\begin{array}{l}\text { Boş (serbest) zamanlarımda fiziksel aktivite yapmaktan } \\
\text { hoşlanırım. }\end{array}$ & 0.64 & 12.26 & & \\
\hline $\begin{array}{l}\text { Fiziksel aktivite hakkında arkadaşlarımla konuşmaktan } \\
\text { zevk alırım. }\end{array}$ & 0.63 & 12.35 & & \\
\hline $\begin{array}{l}\text { Fiziksel aktiviteden sonra zihinsel ve bedensel olarak } \\
\text { rahatladığımı düşünürüm. }\end{array}$ & 0.61 & 16.30 & & \\
\hline Fiziksel aktivite beni sosyal hayata hazırlar. & 0.40 & 9.35 & & \\
\hline \multicolumn{5}{|l|}{ Sosyalleşme } \\
\hline $\begin{array}{l}\text { Fiziksel aktivite sırasında yeni insanlar tanımaktan } \\
\text { hoşlanırım. }\end{array}$ & 0.70 & 14.14 & \multirow{4}{*}{0.75} & \multirow{4}{*}{$\% 5.09$} \\
\hline $\begin{array}{l}\text { Fiziksel aktivite yaparken başkaları ile işbirliği yapmaktan } \\
\text { hoşlanırım. }\end{array}$ & 0.68 & 16.17 & & \\
\hline $\begin{array}{l}\text { Fiziksel aktivite esnasında öğretmenimin/ antrenörümün } \\
\text { her talimatını yerine getiririm. }\end{array}$ & 0.66 & 15.05 & & \\
\hline Fiziksel aktivite yaparken işbirliği duygularım gelişir. & 0.52 & 15.26 & & \\
\hline \multicolumn{5}{|l|}{ Öz Güven } \\
\hline $\begin{array}{l}\text { Fiziksel aktiviteler hakkında başkalarıyla konuşmak beni } \\
\text { rahatsız eder.* }\end{array}$ & 0.73 & 10.00 & \multirow{4}{*}{0.70} & \multirow{4}{*}{$\% 4.20$} \\
\hline Fiziksel aktivitelerde iddialı değilim.* & 0.62 & 10.55 & & \\
\hline Fiziksel aktivite yaparken ön plana çıkmaktan sakınırım.* & 0.59 & 10.10 & & \\
\hline Fiziksel aktivite yapmanın zor olduğunu düşünürüm.* & 0.56 & 11.60 & & \\
\hline Toplam & & & 0.91 & $\% 60.16$ \\
\hline
\end{tabular}

*Ters kodlanan maddeler.

t-değerleri 430 veri ile yürütülen doğrulayıcı faktör analizi sonucunda elde edilmiştir.

Doğrulayıcı Faktör Analizine Yönelik Bulgular: Doğrulayıcı faktör analizi ile açımlayıcı faktör analizinin sunduğu bilgilerle oluşturulan modelin doğrulanıp doğrulanmadığı sınanmıştır. Bu bağlamda, doğrulayıcı faktör analizi ile elde edilen modelde 25 gözlenen değişkenin 5 farklı örtük değişkeni (açımlayıcı faktör analizinden elde edilen alt boyutlar) doğru bir şekilde yordayabildiğini varsayan bir eşitlik kurulmuş ve test edilmiştir. Doğrulayıcı faktör analizi sonuçlarına göre Ki-Kare Uyum Testi 514.602 ve istatiksel olarak anlamlı bulunmuştur $(\mathrm{p}<0.05)$. Ki-Kare değerinin serbestlik 
derecesine oranı ise 1.964 'dır. Ki-kare değeri, kuramsal model ve bu modele bağlı gözlenen değerler arasındaki uyumu göstermektedir. Serbestlik derecesinin büyük olması x2 derecesinin anlamlı çıkmasına neden olabilmektedir ve bu durumdan dolayı x2/sd modelin uyumunu değerlendirmede önemli bir ölçüt olarak kullanılmaktadır (Şimşek, 2007). Tabachnik ve Fidell (2007) x2'nin serbestlik derecesine oranının ikiden küçük olmasının, Kline (2011) ise bu değerin üçten küçük olmasının modelin mükemmel uyum gösterdiğini ifade etmişlerdir. Meydan ve Şeşen (2011) modellerin değerlendirilmesinde kullanılan uyum indeksleri üzerinde bir uzlaşmanın olmadığını belirtmişlerdir. Bu araştırmada incelenen karşılaştırmalı uyum indekslerinden RMSEA 0.048, NNFI 0.927, CFI 0.937, IFI 0.937, RMR 0.061, SRMR ise 0.046 olarak bulunmuştur. Mutlak uyum indekslerinden GFI 0.909 olarak hesaplanmıştır. Modelin iyi uyum göstermesi için RMSEA değerinin 0.7'den küçük olması gerekmektedir (Steiger, 2007). RMR ve SRMR değerlerinin 0 ve 0.10 arasında olmasının modelin kabul edilebilir uyum gösterdiği belirtilmiştir (Hu ve Bentler, 1999; Kline, 2011). Ayrıca, GFI, CFI ve NNFI değerlerinin 0.90'dan büyük olması oluşturulan model ile gözlemlenen değerler arasındaki iyi uyumu göstermektedir (Steiger, 2007; Raykov ve Marcoulides, 2000; Hooper ve diğ., 2008). Bu sonuçlara göre, Fiziksel Aktiviteye Yönelik Tutum Ölçeğinin değerlendirilen tüm uyum indekslerinin kabul edilebilir oranlarda olduğu bulgusuna ulaşılmıştır.

Doğrulayıcı faktör analizi sonuçlarına göre açımlayıcı faktör analizinden elde edilen 5 faktörlü yapı tekrar toplanan veri tarafından da doğrulanmış yani veri seti ve 5 faktörlü yapı arasında iyi derecede bir uyum olduğundan söz edilebilir (Byrne, 2001; Frias ve Dixon, 2005; Meydan ve Şeşen, 2011). Bu araştırma sonucunda elde edilen uyum indeks değerlerinin, alan yazında yer alan referans değerler ile karşılaştırılması ise Tablo 2' de sunulmuştur. Son olarak AMOS yazılımının önerileri doğrultusunda aynı alt boyutlarda yer alan maddeler arasında (Meydan ve Şeşen, 2011), uyum indeks değerlerinin iyileştirilmesi için modifikasyonlar yapılmıştır. Bu modifikasyonların iki tanesi isteklilik, bir tanesi ise fayda alt boyutlarında yer almaktadır. Doğrulayıcı faktör analizine ilişsin diyagram Şekil 1'de görülmektedir.

Tablo 2. Referans uyum indeksleri ve ölçme aracına ilişkin bulgular

\begin{tabular}{llcl}
\hline Uyum İndeksleri & \multicolumn{1}{c}{ Referans Değerler } & Bulgular & Kaynak \\
\hline $\mathrm{X}^{2} / \mathrm{df}$ & $0 \leq \mathrm{X}^{2} / \mathrm{df} \leq 5$ & 1.964 & Tabachnick ve Fidel (2007) \\
$\mathrm{RMSEA}$ & $0 \leq \mathrm{RMSEA} \leq 0.07$ & 0.048 & Steiger (2007) \\
$\mathrm{SRMR}$ & $0 \leq \mathrm{SRMR} \leq 0.10$ & 0.046 & Hu ve Bentler (1999), Kline (2011) \\
$\mathrm{RMR}$ & $0 \leq \mathrm{RMR} \leq 0.10$ & 0.061 & Hu ve Bentler (1999), Kline (2011) \\
NNFI & $0.90 \leq \mathrm{NNFI} \leq 1.00$ & 0.927 & Steiger(2007) \\
CFI & $0.90 \leq \mathrm{CFI} \leq 1.00$ & 0.937 & Raykov ve Marcoulides(2000) \\
GFI & $0.90 \leq \mathrm{GFI} \leq 1.00$ & 0.909 & Hooper ve diğ.(2008) \\
\hline
\end{tabular}

Fiziksel Aktiviteye Yönelik Tutum Ölçeğinin ayrışma geçerliğinin tespiti için ölçek içerisinde bulunan alt boyutlar arasındaki korelasyonlar incelenmiştir. En zayıf ilişski Sevgi ve Güven alt boyutları arasında görülürken, en güçlü ilişkiler Sosyalleşme ve Sevgi ile Sosyalleşme ve Fayda alt boyutları arasındadır. İlişkilerin tamamı pozitif yöndedir. Kline (2011) alt boyutlar arası korelasyonunun ayrışma geçerliğini sağlayabilmesi için korelasyon katsayısının 0.85 'i geçmemesi gerektiğini belirtmiştir.

Tablo 3. Alt boyutlar arası korelasyonlar

\begin{tabular}{lcccc}
\hline Alt Boyutlar & Sevgi & İsteklilik & Fayda & Sosyalleşme \\
\hline Sevgi & 1 & & & \\
\hline İsteklilik & 0.44 & 1 & 1 & \\
\hline Fayda & 0.61 & 0.32 & 0.69 & 1 \\
\hline Sosyalleşme & 0.69 & 0.41 & 0.40 & 0.36 \\
\hline Güven & 0.31 & 0.55 & & 1 \\
\hline
\end{tabular}




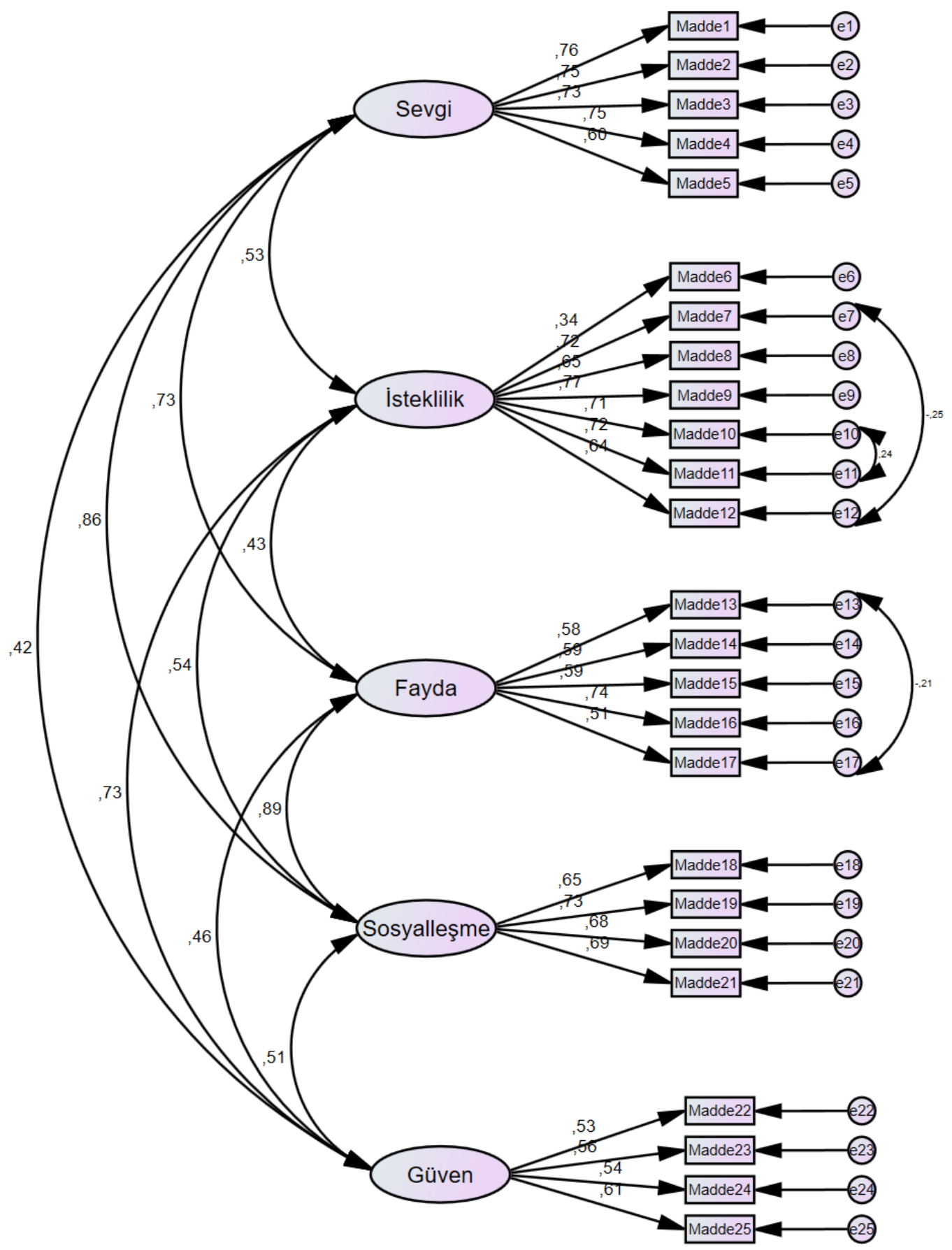

Şekil 1. 5 faktörlü ölçme modeline ilişkin diyagram

Güvenirlik Çalışmasına İlişkin Bulgular: Alt boyutların Cronbach Alfa katsayısına göre hesaplanan güvenirlik değerleri İsteklilik için 0.85 , Sevgi için 0.83 , Sosyalleşme için 0.82 , Fayda için 0.75 ve Öz Güven için 0.70 olarak hesaplanmıştır. Tüm maddeler birlikte analiz edildiğinde ise güvenirlik katsayısı 0.91 olarak hesaplanmıştır. Bu bulgular 1şığında ölçme aracının toplamı ve tüm alt boyutları güvenilirdir (Büyüköztürk, 2007; Tabachnik ve Fidell, 2007). 


\section{TARTIŞMA}

$\mathrm{Bu}$ araştırma çocukluk döneminden adölesan döneme geçiş aşamasında olan ve fizyolojik, sosyo-duyuşsal ve bilişsel açıdan birçok değişimi deneyimleyen ortaokul öğrencilerine yönelik Fiziksel Aktiviteye Yönelik Tutum Ölçeği geliştirmek için yürütülmüştür. Ölçek maddelerinin hazırlanmasında, kapsam ve yüzeysel geçerliğin tespitinde, beden eğitimi ve spor ile fiziksel aktivite konusunda uzman olan öğretim görevlilerinden ve beden eğitimi öğretmenlerinden görüş alınmıştır. Yürütülen pilot uygulama sonucunda anlaş1ılılı̆g tespit edilen ve son hali verilen ölçme aracının yapı geçerliğinin tespiti için açımlayıcı ve doğrulayıcı faktör analizleri yürütülmüştür. Özdeğeri 1'in üzerinde olan ve 25 maddeden oluşan 5 faktörlü yapının, toplam varyansın \%60.16'sını açıklamaktadır. Açıklanan toplam varyansın, alanyazın incelendiğinde yeterli olduğu görülmektedir (Scherer, 1988). İncelenen karşılaştırmalı ve mutlak uyum indekslerinin de literatürde geçen referans değerleri karşıladığı ve ortaokul öğrencilerine yönelik Fiziksel Aktiviteye Yönelik Tutum Ölçeği’nin bu açıdan yapı geçerliğine sahip olduğu görülmektedir. İç tutarlık katsayısı ile hesaplanan güvenirlik değerlerinin de her alt boyut için yeterli olduğu bulunmuştur.

Adölesan ve çocuklarda, fiziksel aktivite davranışının ortaya çıkmasındaki en önemli bileşenlerden bir tanesi fiziksel aktiviteye yönelik tutumdur (Spruijt-Metz \& Saelens, 2016). Türkiye'de adölesanların fiziksel aktivite tutumunun ölçümüne ilişkin yürütülen çalışmalar incelendiğinde, araştırmaların genel olarak beden eğitimi ve spor dersine yönelik tutum ve sportif etkinliklere yönelik tutumu incelemeye yönelik ölçme araçlarını içerdiği görülmektedir (Şentürk, 2015; Güllü \& Güçlü, 2009; Koca \& Aş̧̧1, 2004). Welk, Eisenmann ve Dollman (2006) fiziksel aktivitenin tüm sportif etkinliklerin üzerinde bir şemsiye terim olduğunu ve hayata yönelik genel bir tutum olduğu belirtmiştir. Bu bağlamda fiziksel aktiviteye yönelik bir ölçme aracının Türk kültüründe ortaokul öğrencileri için geliştirilmiş olması önem taşımaktadır. Ulusal literatür incelendiğinde ortaokul öğrencileri için fiziksel aktiviteye yönelik tutumun ölçülmesine ilişkin herhangi bir ölçme aracının geliştirilmediği, tutumu ölçmek için ise Amerika'da 18-25 yaş arası bireyler için geliştirilen "Bilişsel Davranış̧ı Fiziksel Aktivite Ölçeği”nin, Türkiye'de 13-17 yaş arasındaki adölesan bireylerde geçerli ve güvenilir bulunmuştur (Eskiler, Küçükibiş, Gülle, \& Soyer, 2016). Bu ölçme aracının alt boyutları ve ilgili 15 madde incelendiğinde öz-düzenleme, sonuç beklentisi ve fiziksel aktiviteye yönelik algıllanan engelleri içerdiği görülmektedir. Corbin ve diğ. (2014) tarafindan oluşturulan ve fiziksel aktiviteye yönelik tutumu sağlık ve fiziksel uygunluk, görünüş, eğlence, rahatlama, meydan okuma, sosyallik, yarışma, iyi hissetme ve açık alan etkinlikleri alt boyutlarından oluşan 18 maddelik "Fiziksel Aktiviteye Yönelik Tutum Ölçeği” uluslararası literatürde bulunan bir diğer alternatif ölçme aracıdır. $\mathrm{Bu}$ ölçme aracında yer alan alt boyutların her birisi iki madde içermektedir. Ancak, Marsh (2007) ölçme aracında yer alan bir faktörün psikometrik açıdan güçlü olabilmesi için en az üç maddeyi içermesi gerektiğini belirtmiştir. Bu bağlamda araştırma sonucunda oluşturulan, ortaokul öğrencilerinde geçerli ve güvenilirliği tespit edilen Fiziksel Aktiviteye Yönelik Tutum Ölçeğinin güçlü bir alternatif ölçme aracı olduğu söylenebilir.

$\mathrm{Bu}$ araştırma sonucunda, 25 madde ile fiziksel aktiviteye yönelik algılanan Sevgi, İsteklilik, Fayda, Sosyalleşme, Güven alt boyutlarındaki tutumu ölçen Fiziksel Aktiviteye Yönelik Tutum Ölçeği, farklı yapıların değerlendirilmesine olanak sağlamaktadır.

Ölçme aracının madde havuzunun oluşturulmasında uzman görüşleri ve literatürde önceden yürütülen çalışmalara önem verilerek görünüş ve kapsam geçerliğinin sağlanmasına özen gösterilmeye çalışılmıştır. Ölçme aracının madde havuzu ile yürütülen açımlayıcı faktör analizi sonucunda madde faktör yükleri ve bazı maddelerin binişik olmasından dolayı, madde sayıs1 25'e düşmüştür. Bu durum daha önce belirtildiği üzere uzun ölçme araçlarının oluşturduğu bilişsel 
yük nedeniyle farklı ölçme araçlarıyla birlikte kullanmalarının önünde oluşan engelin aşılmasında bir avantaj olarak değerlendirilebilir (Aş̧̧ı ve diğ., 2017; Çağlar, Aşçı, \& Bilgili, 2017).

\section{SONUÇ VE ÖNERILER}

Fiziksel Aktiviteye Yönelik Tutum ölçeğinin geliştirilmesine yönelik elde edilen geçerlik ve güvenirlik değerleri doğrultusunda, 12-15 yaş arasındaki ortaokul öğrencilerinin fiziksel aktiviteye yönelik algılarının isteklilik, sevgi, fayda, sosyalleşme ve özgüven alt boyutlarının tespit edilmesinde geçerli ve güvenilir bir biçimde kullanılabilir.

Fiziksel Aktiviteye Yönelik Tutum ölçeğinin geliştirildiği bu çalışmanın yöntemsel sınırlılıkları göz önünde bulundurulmalıdır. Örneğin; elde edilen bulgular Ankara kent merkezinde 6., 7. ve 8. sinıf öğrencilerinden toplanan verilerin birer yansımasıdır. Gelişim düzeyi, yaşanılan çevre ve sosyo-ekonomik etmenler gibi faktörlerin fiziksel aktivite davranışını etkileyeceği düşünüldüğünde, ölçme aracının kırsal kesimde yaşayan adölesanlar için ya da farklı yaş gruplarından bireyler için geçerlik ve güvenirliğinin incelenmesinde fayda vardır. Öğretmenlerin ve ailelerin fiziksel aktiviteye yönelik tutumların belirleyecek ölçekler geliştirilip, öğrenci, öğretmen ve velinin de dahil edildiği daha kapsamlı çalışmalar yapılabilir. Bu çalışmalar sonucunda el edilen bulgular fiziksel aktivitenin teşvikine ilişkin politikaların yapılandırılmasının önünü açabilir.

$\mathrm{Bu}$ araştırmada ölçme araçları Etik Kurul izni doğrultusunda beden eğitimi ve spor dersinde toplanmıştır. Bu durum ölçme aracını dolduran ve fiziksel aktivite davranışını beden eğitimi ve spor dersi ile ilişkilendiren öğrenciler için cevaplara yönelik etki oluşturabilir. Ölçme aracını kullanacak araştırmacıların bu sınırlılığa dikkat etmesi önerilmektedir. Ayrıca güvenirlik değerinin test tekrar test yöntemi gibi farklı güvenirlik teknikleriyle incelenmesi daha güvenilir sonuçlar ortaya koyabilir.

\section{KAYNAKLAR}

1. Aş̧̦, FH., Maïano, C., Morin, AJS., Çağlar, E., Bilgili, N. (2017). Validity and reliability of the Very Short form of the Physical Self-Inventory among Turkish adolescents. Journal of Sports Sciences, 35(21), 2060-2066.

2. Ajzen I. (2001). Nature and Operation of Attitudes. Annual Review of Psychology, 52(1), 27-58.

3. Ajzen I. (2005). Attitudes, Personality, And Behavior. McGraw-Hill Education: London, UK.

4. Aksoydan E, Çakır N. (2011). Adölesanların beslenme alışkanlıkları, fiziksel aktivite düzeyleri ve vücut kitle indekslerinin değerlendirilmesi. Gülhane Tip Dergisi, 53, 264-270.

5. Büyüköztürk Ş. (2007). Sosyal Bilimler için Veri Analizi El Kitabı. Ankara: Pegem Yayıncılık.

6. Byrne BM. (2001). Structural Equation Modeling with AMOS: Basic Concepts, Applications, and Programming. NJ: Mahwah.

7. Cengiz C, İnce ML. (2014). Impact of social-ecologic intervention on physical activity knowledge and behaviors of rural students. Journal of Physical Activity and Health, 11 (8), 1565-1572.

8. Creswell JW. (2017). Karma Yöntem Araştırmalarına Giriş. (M. Sözbilir, Ed.). Ankara: Pegem Akademi.

9. Corbin, CB, Welk, GJ, Corbin, WR, Welk, KA. (2014). Concepts of Physical Fitness: Active lifestyles for wellness. New York: McGraw Hill.

10. Çağlar E, Aşçı FH, Bilgili N. (2017). Üniversite Öğrencilerinde Fiziksel Benlik Ölçeği Türkçe Sürümünün Psikometrik Özellikleri. Anatolian Journal of Psychiatry, 18(6), 594-601.

11. Deryakulu D. (2004 ). Epistemolojik inançlar, içinde: Y. Kuzgun, D. Deryakulu (Ed.), Eğitimde Bireysel Farklllıklar, Ankara: Nobel YayınDağıtım, 259-287.

12. Eskiler E, Küçükibiş F, Gülle M, Soyer F. (2016). Bilişsel Davranışçı Fiziksel Aktivite Ölçeği: Geçerlik ve Güvenirlik Çalışması. Uluslararası Insan Bilimleri Dergisi, 13(2), 2577-2587.

13. Field A. (2009). Discovering Statistics Using SPSS (3rd ed.). Thousand Oaks, CA: SAGE Publications.

14. Fraenkel, JR, Wallen NE, Hyun H. (2012). How to Design and Evaluate Research in Education (8th ed.). New York: McGraw Hill.

15. Frias CM, Dixon RA. (2005). Confirmatory factor structure and measurement invariance of the memory compensation questionniare. Psychological Assessment, 17, 168-178. 
16. Güllü, M., Güçlü, M. (2009). Ortaöğretim öğrencileri için beden eğitimi dersi tutum ölçeği geliştirilmesi. Beden Egitimi ve Spor Bilimleri Dergisi, 3(2).

17. Halfon N, Hochstein M. (2002). Life course health development: an integrated framework for developing health, policy, and research. The Milbank Quarterly, 80(3), 433-479.

18. Hills AP, King NA, Armstrong TP. (2007). The contribution of physical activity and sedentary behaviours to the growth and development of children and adolescents: implications for overweight and obesity. Sports Medicine, 37(6): 533-545.

19. Hooper D, Coughlan J, Mullen M. (2008). Structural equation modelling: Guidelines for determining model fit. Electronic Journal of Business Research Methods, 6(1), 53-60.

20. Hu LT, Bentler PM. (1999). Cutoff criteria for fit indexes in covariance structure analysis: Conventional criteria versus new alternatives. Structural Equation Modeling: A Multidisciplinary Journal, 6(1), 1-55.

21. Kemper HC, Post GB, Twisk JW, Van Mechelen W. (1999). Lifestyle and obesity in adolescence and young adulthood: results from the Amsterdam Growth And Health Longitudinal Study (AGAHLS). Int. J. Obes. Relat. Metab. Disord. 23 (Suppl. 3): S34-S40

22. Kline RB. (2011). Principles And Practice Of Structural Equation Modeling (3. ed.). NY: The Guillford Press.

23. Koca C., Aş̧̧, FH. (2004). Atletik yeterlik düzeyi ve cinsiyetin beden eğitimine yönelik tutum üzerine etkisi. Gazi Beden Eğitimi ve Spor Bilimleri Dergisi, 9(1), 15-24.

24. Lewis BA, Marcus BH, Pate RR, Dunn AL. (2002). Psychosocial mediators of physical activity behavior among adults and children. American Journal of Preventive Medicine, 23(2), 26-35.

25. Linda Rikard G, Banville D. (2006). High school student attitudes about physical education. Sport, Education and Society, 11(4), 385-400.

26. Luepker RV, Perry CL, McKinlay SM, Nader PR, Parcel GS, Stone EJ ve diğ. (1996). Outcomes of a field trial to improve children's dietary patterns and physical activity: the Child and Adolescent Trial for Cardiovascular Health (CATCH). Jama, 275(10), 768-776.

27. Marcus BH, Forsyth LH, Stone, EJ, Dubbert PM, McKenzie TL, Dunn AL ve diğ. (2000). Physical activity behavior change: issues in adoption and maintenance. Health Psychology, 19(1S), 32.

28. Marsh, HW. (2007). Application of confirmatory factor analysis and structural equation modeling in sport and exercise psychology. In G. Tenenbaum \& R. . Eklund (Eds.), Handbook of sport psychology (3rd ed., pp. 774-789). Hoboken, NJ: British Psychological Society.

29. Meydan CH, Şeşen H. (2011). Yapısal Eşitlik Modellemesi AMOS Uygulamaları. Ankara: Detay Yayıncılık.

30. Milosis DC, Papaioannou AG, Siatras TA, Proios M, Proios M. (2015). Gender Differences on Attitudes and Participation in an Extracurricular Gymnastics Course Among Greek University Students. Journal of Teaching in Physical Education, 34(3), 424-441.

31. Morgan CT. (2009). Psikolojiye Giriş. (S. Karakaş \& R. Eski, Ed.) (19th ed.). Konya: Eğitim Kitabevi Yayınları.

32. Özdamar K. (2013). Paket Programlar ile İstatiksel Veri Analizi-II. Eskişehir: Nisan Kitabevi.

33. Pate RR, McIver KL, Colabianchi N, Troiano RP, Reis JP, Carroll DD ve diğ. (2015). Physical activity measures in the Healthy Communities Study. American Journal of Preventive Medicine, 49(4), 653-659.

34. Raykov T, Marcoulides GA. (2000). A First Course In Structural Equation Modeling. New Jersey: Lawrence Erlbaum Associates.

35. Ruiz JR, Ortega FB, Martinez-Gomez D, Labayen I, Moreno LA, De Bourdeaudhuij I. ve diğ. (2011). Objectively measured physical activity and sedentary time in European adolescents: the HELENA study. Am J Epidemiol.174:173-84.

36. Scherer RF. (1988). Dimensionality of coping: Factor stability using the ways of coping questionnaire. Psychological Report, 62, 76-77.

37. Spruijt-Metz D, Saelens BE. (2016). 14 Behavioral Aspects of Physical Activity in Childhood and Adolescence. Handbook of pediatric obesity: Etiology, pathophysiology, and prevention, M.I Goran and M.S. Sothern (Eds.). Taylor and Francis: New York.

38. Steiger JH. (2007). Understanding the limitations of global fit assessment in structural equation modeling. Personality and Individual Differences, 42(5), 893-898.

39. Strong WB, Malina RM, Blimkie CJR, Daniels SR, Dishman RK.; Gutın B. ve diğg. (2005). Evidence based physical activity for school-age youth. The Journal of Pediatrics, 146(6): 732-737.

40. Ş̧entürk HE. (2015). Sportif tutum ölçeği: geliştirilmesi, geçerliliği ve güvenirliği. CBÜ Beden Eğitimi ve Spor Bilimleri Dergisi, 7(2), 8-18.

41. Şimşek ÖF. (2007). Yapısal eşitlik modellemesine giriş: Temel ilkeler ve LISREL uygulamaları. Ankara: Ekinoks Yayıncılık.

42. Tabachnick BG, Fidell LS. (2007). Using Multivariate Statistics (5th ed.). Upper Saddle River, NJ: Pearson Allyn \& Bacon.

43. Taylor WC, Blair, SN, Cummings SS, Wun CC, Malina, RM. (1999). Childhood and adolescent physical activity patterns and adult physical activity. Med. Sci. Sports Exerc. 31: 118-123.

44. Türkiye Cumhuriyeti Sağık Bakanlığı (2010). Türkiye Beslenme ve Sağlık Araş̧tırmast. 20.03.2019, https://hsgm.saglik.gov.tr/depo/birimler/saglikli-beslenme-hareketli-hayat-db/Yayinlar/kitaplar/diger-kitaplar/TBSA-Beslenme-Yayini.pdf.

45. Twisk JW, Kemper HC, Van Mechelen W. (2000). Tracking of activity and fitness and the relationship with cardiovascular disease risk factors. Med. Sci. Sports Exerc. 32:1455-1461. 
46. Van Mechelen W, Twisk JW, Post GB, Snel J, Kemper HC. (2000). Physical activity of young people: the Amsterdam Longitudinal Growth and Health Study. Med Sci Sports Exerc:;32:1610-6.

47. World Health Organization (2010). Global recommendations on physical activity for health. Geneva: World Health Organization, 60. https://doi.org/10.1080/11026480410034349.

48. World Health Organization (2014). Global status report on non-communicable diseases. 21.03.2019, http://apps.who.int/iris/bitstream/10665/148114/1/9789241564854_eng.pdf?ua=1.

49. Yıldıer G, Bilgin E, Korur EN, Novak D, Demirhan G. (2018). The association of various social capital indicators and physical activity participation among Turkish adolescents. Journal of Sport and Health Science, 7(1), 27-33. 